Archived version from NCDOCKS Institutional Repository http://libres.uncg.edu/ir/asu/

\title{
Appalachỉan
}

B O O N E, NORT H C A R O L I A

\section{Isolation Of A Novel Acidiphilic Methanogen From An Acidic Peat Bog}

\author{
By: Suzanna L. Brauer, Hinsby Cadillo-Quiroz, Erika Yashiro, Joseph B. \\ Yavitt \& Stephen H. Zinder
}

\begin{abstract}
Acidic peatlands are among the largest natural sources of atmospheric methane and harbour a large diversity of methanogenic Archaea1. Despite the ubiquity of methanogens in these peatlands, indigenous methanogens capable of growth at acidic $\mathrm{pH}$ values have resisted culture and isolation2-4; these recalcitrant methanogens include members of an uncultured family-level clade in the Methanomicrobiales prevalent in many acidic peat bogs in the Northern Hemisphere 1,5,6. However, we recently succeeded in obtaining a mixed enrichment culture of a member of this clade7. Here we describe its isolation and initial characterization. We demonstrate that the optimum $\mathrm{pH}$ for methanogenesis by this organism is lower than that of any previously described methanogen.
\end{abstract}

Suzanna L. Brauer, Hinsby Cadillo-Quiroz, Erika Yashiro, Joseph B. Yavitt \& Stephen H. Zinder. (2006). "Isolation Of A Novel Acidiphilic Methanogen From An Acidic Peat Bog." Nature, 442:192-194. [ISSN: 00280836] [DOI 10.1038/nature04810] Version Of Record Available At www.nature.com 


\section{Introduction}

It has been estimated that northern peatlands contain one-third of the carbon found in soils worldwide 8 . They are important sources of atmospheric methane, a greenhouse gas whose concentration has more than doubled in the past 200 years (ref. 9), reaching levels unprecedented in the past 650,000 years (ref. 10). Sphagnum-dominated bogs, the predominant peatlands ${ }^{11}$, are typically acidic $(\mathrm{pH}<5)$ with low concentrations of mineral nutrients. Acidiphilic aerobic methaneoxidizing organisms have been isolated ${ }^{12}$, whereas attempts to isolate acidiphilic methanogens from bogs were unsuccessful ${ }^{2,13}$.

$16 \mathrm{~S}$ rRNA-based culture-independent studies indicate that the methanogens present in acidic bogs comprise several novel genera and species ${ }^{1,5,6,11}$. A family-level clade in the $\mathrm{H}_{2} / \mathrm{CO}_{2}$-using methanoarchaeal order Methanomicrobiales-originally called the R10 group $^{5}$, and also called the fen cluster ${ }^{7,14}$ or E1/E2 cluster ${ }^{15}$-is usually abundant in $16 \mathrm{~S}$ rRNA clone libraries from acidic peat bogs in diverse geographical locations ${ }^{1,5,6,16}$. For example, in McLean Bog, New York State, a small acidic ( $\mathrm{pH} 4.1$ ) bog we study, 66 out of 84 methanogen 16S rRNA gene clones belonged to this clade ${ }^{1}$. More recent studies using quantitative polymerase chain reaction (PCR) showed nearly $10^{9}$ cells per gram dry weight of this group in active layers of McLean Bog peat, about half of the total Archaea ${ }^{15}$. Recently, sequences in the R10 group were detected as minority members of low-pH methanogenic enrichment cultures from German or Siberian bogs ${ }^{3,4}$.

We recently demonstrated that the antibiotic rifampicin allowed enrichment of $\mathrm{H}_{2} / \mathrm{CO}_{2}$-using methanogenic Archaea in McLean Bog peat, and prevented growth of $\mathrm{H}_{2} / \mathrm{CO}_{2}$-using acetogenic Bacteria ${ }^{7,17}$. Using results from experiments examining the physical and chemical conditions that favoured methanogenesis ${ }^{17}$, we designed a low-ionicstrength medium, designated PM1, that allowed repeated transfer of $\mathrm{H}_{2} / \mathrm{CO}_{2}$-using methanogens at $\mathrm{pH} 5$ (ref. 7). Dilutions in liquid medium to $10^{-8}$, the correct order of magnitude for a dilution to extinction, produced a culture, designated $6 \mathrm{~A} 8$, containing two morphotypes-thin straight rod cells $(0.2-0.3 \mu \mathrm{m}$ diameter, $0.8-3.0 \mu \mathrm{m}$ long) and irregular coccoid cells $(0.3-0.8 \mu \mathrm{m}$ in diameter) (Fig. 1a, b). The coccoid cells represented 5-8\% of total cells and were present in all growth phases.
We initially assumed that the coccoid cells were heterotrophic bacterial contaminants; however, no growth or methanogenesis was detected in medium amended with various organic substrates, and PCR amplifications with the universal bacterial 16S rRNA gene primers $27 \mathrm{f}$ and $1492 \mathrm{r}$ were negative. All of 39 clones amplified with primers $1 \mathrm{Af}(-1)$ and $1100 \mathrm{Ar}$ for methanogens ${ }^{1,5}$ were a single restriction type, and a 92-clone library generated using broad-range archaeal primers (1Af and ArchLSU47) that amplified a region encoding 16S rRNA, the 16S-23S internal transcribed spacer (ITS) region, and part of the $23 \mathrm{~S}$ rRNA (1,730 base pairs in total), yielded sequences with $\geq 99.7 \%$ identity, within the error rate expected for PCR amplification ${ }^{18,19}$. The 6A8 $16 \mathrm{~S}$ rRNA gene sequence belonged to the R10-Fen cluster-E1/E2 family, most closely related to sequences from mixed cultures (Supplementary Fig. 1).
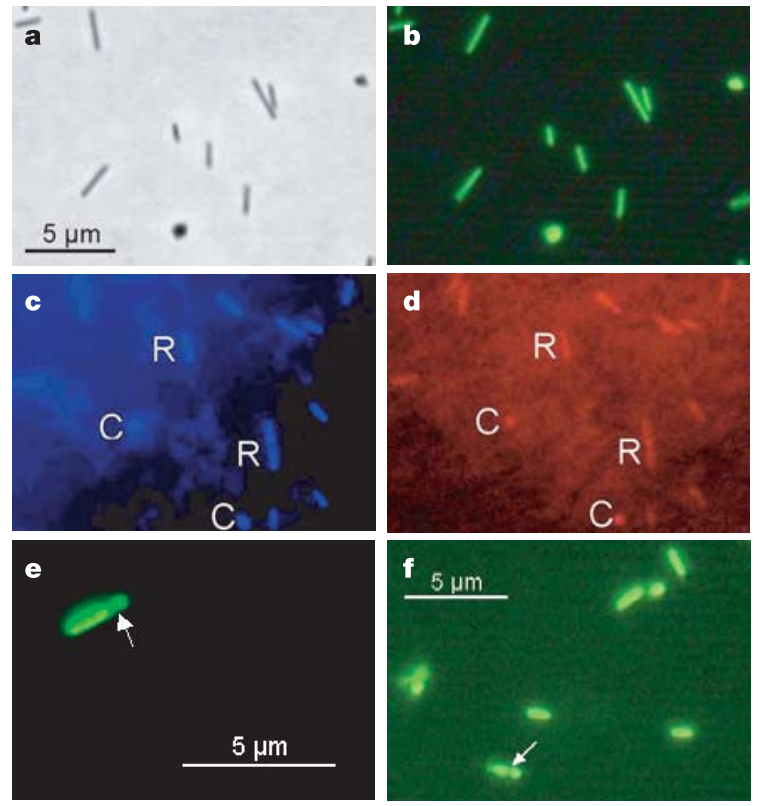

Figure 1 | Photomicrographs of culture 6A8. a, b, Phase contrast (a) and fluorescence (b) images of cells in the same field of view, stained with the DNA stain acridine orange (AO), showing thin rod and coccoid morphologies. c, d, Fluorescence micrographs of rod-shaped (R) and coccoid (C) cells in 6A8 stained with the DNA stain 4,6-diamidino-2phenylindole (DAPI) (c) or with a Cy-3-labelled 16S rRNA probe targeting 6A8, probe $6 \mathrm{A8} 644$ (d). e, AO-stained cell apparently undergoing asymmetric division to a coccoid cell (arrow). f, AO-stained cells passed through a $0.45-\mu \mathrm{m}$ membrane filter and then concentrated, showing short rods and small cocci, including a cell apparently undergoing asymmetric division (arrow). 


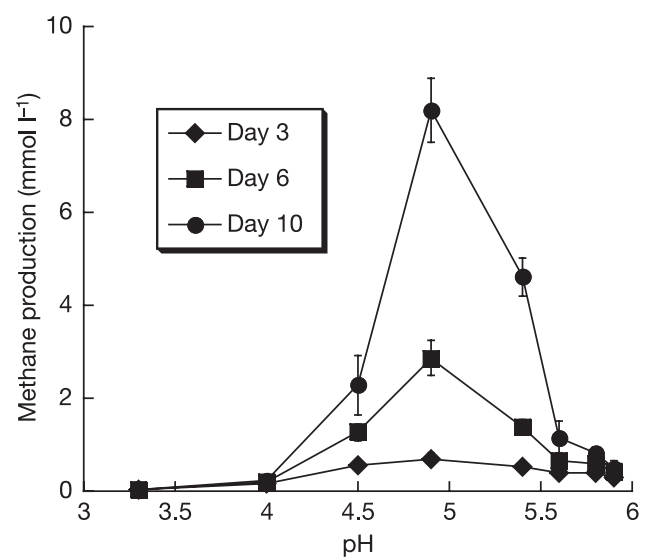

Figure 2 | Effect of pH on methanogenesis by culture $6 \mathrm{A8}$ grown at $28^{\circ} \mathrm{C}$. Data points represent the averages and error bars the standard errors for triplicate samples.

Fluorescence in situ hybridization (FISH) staining of rRNA allows more positive identification of organisms. Initial attempts to stain these cells failed, but a FISH protocol developed for SAR11 (ref. 20), also difficult to stain, allowed visualization of both morphotypes with the universal ARCH 915 probe, but not with the EUB 338 probe (data not shown). Probe MG12006A8, in which a single-base mismatch with the 'universal' Methanomicrobiales probe MG1200 (ref. 21) was corrected, hybridized with both morphotypes (Supplementary Fig. 2), as did the strain-specific probe, 6A8 644 (Fig. 1c, d), which did not stain cells from the most closely related isolate, Methanospirillum hungatei JF1 (Supplementary Fig. 2).

During microscopic examination of growing cultures, cell division in rod-shaped cells was observed, but not in coccoid cells. Division in the rod-shaped cells was sometimes asymmetrical ${ }^{22}$, giving rise to spherical cells (Fig. 1e). Filtration of cultures through a $0.45-\mu \mathrm{m}$ filter allowed passage of short rods and small coccoid cells (Fig. 1f). In cultures grown out from this filtrate, long rods and large coccoid cells returned, and indeed Fig. 1a, b shows such a culture. From these observations, we conclude that both morphotypes are manifestations of the same organism, and suggest that the large coccoid cells are non-viable cultural artefacts.

$6 \mathrm{~A} 8$ used $\mathrm{H}_{2} / \mathrm{CO}_{2}$ as a methanogenic substrate with a doubling time near two days at $\mathrm{pH} 5.1$ and $28^{\circ} \mathrm{C}$ (standard growth conditions), and did not use formate, ethanol, methanol or acetate. Besides mineral nutrients, it required vitamins, yeast extract, coenzyme $\mathrm{M}$ and low $(<200 \mu \mathrm{M})$ concentrations of acetate in the medium. The optimum $\mathrm{pH}$ for methanogenesis was near 5 (Fig. 2), with little methanogenesis in cultures incubated at $\mathrm{pH} 4.0$ or 5.8 . The temperature optimum was near $37^{\circ} \mathrm{C}$ (Supplementary Fig. 3), with slow methanogenesis at $10^{\circ} \mathrm{C}$ but not at $4{ }^{\circ} \mathrm{C}$.

The most acidiphilic hydrogenotrophic methanogen described to date is Methanobacterium espanolae ${ }^{23}$, with a $\mathrm{pH}$ optimum between 5.5 and 6.0 and a minimum near 4.7. Some strains of Methanosarcina spp. can grow near $\mathrm{pH} 4.5$, although their optimum is near neutrality ${ }^{24}$. Microbial populations converting $\mathrm{H}_{2} / \mathrm{CO}_{2}$ to methane in McLean Bog showed an optimum pH near 5.0 (ref. 17), close to that of $6 \mathrm{~A} 8$, but produced considerably more methane relative to the optimum at $\mathrm{pH}$ values near 4.3 and 5.8 than did culture $6 \mathrm{~A} 8$, indicating that this mixed microbial population had a broader $\mathrm{pH}$ response. Under in situ conditions in McLean Bog peat ( $\left.\mathrm{pH}<4.5,4-20^{\circ} \mathrm{C}\right)$, rates of methanogenesis by this organism would be considerably limited.

In summary, we have isolated a novel acidiphilic methanogen that is part of an indigenous population adapted to conditions in a methanogenic peat bog, a habitat that is not only low in $\mathrm{pH}$, but also low in concentrations of mineral ions such as sodium ${ }^{17}$. $6 \mathrm{~A} 8$ is clearly a member of a novel genus in the order Methanomicrobiales, and based on its preliminary characterization, we propose the name 'Candidatus Methanoregula boonei', describing the morphology of the thin rod (from the Latin regula, meaning slat) and in honour of the late D. Boone, whose pioneering research on anaerobes included studies on extremophilic methanogens growing at low temperatures ${ }^{25}$ or $\mathrm{pH}^{24}$.

\section{METHODS}

Culture growth. Culture 6A8 was grown in anaerobic PM1 medium ${ }^{7}$ buffered to $\sim$ pH 5.1 by the organic buffer Homopipes ( $\mathrm{p} K_{\mathrm{a}}=4.7$ at $28^{\circ} \mathrm{C}$ ). Methane production by cultures was quantified by gas chromatography ${ }^{17}$.

Molecular and phylogenetic analyses. 16S rRNA gene clone libraries were generated from 6A8 DNA by PCR amplification using primers specific to methanoarchaea (1Af(-1) and 1100Ar) or Bacteria (27f and 1492r), or universal archaeal primers (1Af and ArchLSU47) spanning the 16S rRNA gene, the internal transcribed spacer (ITS) region, and part of the 23S rRNA gene. Cloned PCR amplicons were screened by restriction endonuclease digestion, and representative clones were sequenced at Cornell's Bioresource Center and were analysed using ARB and PHYLIP phylogenetic packages.

Fluorescence microscopy. Fluorescence in situ hybridization (FISH) was performed using fixed cells on black polycarbonate membranes ${ }^{20}$. The speciesspecific Cy3-labelled oligonucleotide probe 6A8 644 was designed using the ARB software package. Probe specificity was verified by failure to hybridize with Escherichia coli or M. hungatei JF1 cells. Stained cells were viewed using a Nikon Eclipse E600 microscope equipped with a Hamamatsu CCD digital camera, or an Olympus BX61 microscope equipped with a Cooke SensiCam camera and SlideBook software.

A more detailed description of methods is provided in Supplementary Information.

1. Basiliko, N., Yavitt, J. B., Dees, P. M. \& Merkel, S. M. Methane biogeochemistry and methanogen communities in two northern peatland ecosystems, New York State. Geomicrobiol. J. 20, 563-577 (2003).

2. Williams, R. T. \& Crawford, R. L. Methanogenic bacteria including an acid-tolerant strain from peatlands. Appl. Environ. Microbiol. 50, 1542-1544 (1985).

3. Sizova, M. V., Panikov, N. S., Tourova, T. P. \& Flanagan, P. W. Isolation and characterization of oligotrophic acido-tolerant methanogenic consortia from a Sphagnum peat bog. FEMS Microbiol. Ecol. 45, 301-315 (2003).

4. Horn, M. A., Matthies, C., Küsel, K., Schramm, A. \& Drake, H. L. Hydrogenotrophic methanogenesis by moderately acid-tolerant methanogens of a methane-emitting acidic peat. Appl. Environ. Microbiol. 69, 74-83 (2003).

5. Hales, B. A. et al. Isolation and identification of methanogen-specific DNA from blanket bog peat by PCR amplification and sequence analysis. Appl. Environ. Microbiol. 62, 668-675 (1996).

6. Galand, P. E., Fritze, H. \& Yrjala, K. Microsite-dependent changes in methanogenic populations in a boreal oligotrophic fen. Environ. Microbiol. 5, 1133-1143 (2003).

7. Bräuer, S. L., Yashiro, E., Ueno, N. G., Yavitt, J. B. \& Zinder, S. H. Characterization of acid-tolerant $\mathrm{H}_{2} / \mathrm{CO}_{2}$-utilizing methanogenic enrichment cultures from an acidic peat bog in New York State. FEMS Microbiol. Ecol. (in the press).

8. Gorham, E. Northern peatlands role in the carbon cycle and probable responses to climatic warming. Ecol. Appl. 1, 182-195 (1991).

9. Cicerone, R. J. \& Oremland, R. S. Biogeochemical aspects of atmospheric methane. Glob. Biogeochem. Cycles 2, 299-327 (1988).

10. Brook, E. J. Atmospheric science. Tiny bubbles tell all. Science 310, 1285-1287 (2005).

11. Kotsyurbenko, O. R. et al. Acetoclastic and hydrogenotrophic methane production and methanogenic populations in an acidic West-Siberian peat bog. Environ. Microbiol. 6, 1159-1173 (2004).

12. Dedysh, S. N. et al. Isolation of acidophilic methane-oxidizing bacteria from northern peat wetlands. Science 282, 281-283 (1998).

13. Goodwin, S. \& Zeikus, J. G. Ecophysiological adaptations of anaerobic bacteria to low $\mathrm{pH}$ : analysis of anaerobic digestion in acidic bog sediments. Appl. Environ. Microbiol. 53, 57-64 (1987).

14. Galand, P. E., Saarnio, S., Fritze, H. \& Yrjala, K. Depth related diversity of methanogen Archaea in Finnish oligotrophic fen. FEMS Microbiol. Ecol. 42, 441-449 (2002)

15. Cadillo-Quiroz, H. et al. Vertical profiles of methanogenesis and methanogens in two contrasting acidic peatlands in central New York State, USA. Environ. Microbiol. (in the press).

16. Juottonen, $\mathrm{H}$. et al. Methanogen communities and Bacteria along an ecohydrological gradient in a northern raised bog complex. Environ. Microbiol. 7, 1547-1557 (2005) 
17. Bräuer, S. L., Yavitt, J. B. \& Zinder, S. H. Methanogenesis in McLean Bog, an acidic peat bog in upstate New York: stimulation by $\mathrm{H}_{2} / \mathrm{CO}_{2}$ in the presence of rifampicin, or by low concentrations of acetate. Geomicrobiol. J. 21, 433-443 (2004).

18. Könneke, M. et al. Isolation of an autotrophic ammonia-oxidizing marine archaeon. Nature 437, 543-546 (2005).

19. von Wintzingerode, F., Göbel, U. B. \& Stackebrandt, E. Determination of microbial diversity in environmental samples: pitfalls of PCR-based rRNA analysis. FEMS Microbiol. Rev. 21, 213-229 (1997).

20. Morris, R. M. et al. SAR11 clade dominates ocean surface bacterioplankton communities. Nature 420, 806-810 (2002).

21. Raskin, L., Stromley, J. M., Rittmann, B. E. \& Stahl, D. A. Group specific $16 \mathrm{~S}$ rRNA hybridization probes to describe natural communities of methanogens. Appl. Environ. Microbiol. 60, 1232-1240 (1994).

22. Angert, E. R. Alternatives to binary fission in bacteria. Nature Rev. Microbiol. 3, 214-224 (2005)

23. Patel, G. B., Sprott, G. D. \& Fein, J. E. Isolation and characterization of Methanobacterium espanolae sp. nov., a mesophilic moderately acidophilic methanogen. Int. J. Syst. Bacteriol. 40, 12-18 (1990).

24. Maestrojuan, G. M. \& Boone, D. R. Characterization of Methanosarcina barkeri
$\mathrm{MS}^{\top}$ and 227 Methanosarcina mazei S- $6^{\top}$ and Methanosarcina vacuolata Z-761 ${ }^{\top}$. Int. J. Syst. Bacteriol. 41, 267-274 (1991).

25. Franzmann, P. D. et al. Methanogenium frigidum sp. nov., a psychrophilic, $\mathrm{H}_{2}$-using methanogen from Ace Lake, Antarctica. Int. J. Syst. Bacteriol. 47, 1068-1072 (1997). 